\title{
EXPLORE
}

\section{Sistem Pendukung Keputusan Calon Penerima Program Keluarga Harapan (PKH) Di Dinas Sosial Kota Bengkulu Menggunakan Metode Topsis}

\author{
Erlita, Indra Kanedi, Feri Hari Utami, Asnawati, Yupianti \\ Program Studi Sistem Informasi, Fakultas Ilmu Komputer \\ Universitas Dehasen Bengkulu \\ Bengkulu, Indonesia \\ indradehasen@yahoo.co.id, nidokruan@gmail.com, asna_pkg@yahoo.co.id, Yupiantiprana@gmail.com
}

\begin{abstract}
Abstrak-Sistem Pendukung Keputusan Jumlah Penerima PKH di Dinas Sosial Kota Bengkulu Menggunkan Metode Topsis adalah sebagai berikut Untuk memberikan informasi tentang pengambilan keputusan dengan sesuai kriteria menggunakan metode Topsis sehingga bisa menjadi tolak ukur dalam pengambilan keputusan, Dengan metode ini dapat mempermudah dalam pencarian data yang akurat sebanyak apapun responden yang akan diusulkan berdasarkan kriteria maka sistem akan melacak dan memberikan keputusan yang tepat. Tujuan yang hendak dicapai dalam penelitian ini adalah membuat implementasi algoritma Sistem Pendukung Keputusan Jumlah Penerima Kis PBI Didinas Sosial Kota Bengkulu Menggunkan Metode Topsis, Bagi pembaca diharapkan dapat memperluas wawasan, pengetahuan terhadap perkembangan ilmu Sistem Pendukung Keputusan Jumlah Penerima Kis Pbi Didinas Sosial Kota Bengkulu Menggunkan Metode Topsis, Adapun kesimpulan yang dapat diambil dari penelitian Sistem Pendukung Keputusan Jumlah Penerima PKH di Dinas Sosial Kota Bengkulu Menggunkan Metode Topsis adalah sebagai berikut : Pengambilan keputusan dengan sesuai kriteria menggunakan metode Topsis sehingga bisa menjadi tolak ukur dalam pengambilan keputusan, Dengan metode ini dapat mempermudah dalam pencarian data yang akurat sebanyak apapun responden yang akan diusulkan berdasarkan kriteria maka sistem akan melacak dan memberikan keputusan yang tepat, Mempermudah admin melakukan pencarian dalam berdasarkan bobot dan kreteria, Pada sistem baru ini akan dirancang Sistem Sistem Penerima PKH di Dinas Sosial Kota Bengkulu berbasis Web menggunakan php dan mysql, Metode yang digunakan pada kegiatan penulisan skripsi dan penelitian ini dengan mengunakan metode pengumpulan data, analisa dan perencangan serta implementasai yang dilakukan pengumpulan data, analisa sistem, perancangan, implementasi, dan pengujian.
\end{abstract}

Kata Kunci: SPK, Topsis, Php My-Sq1

\section{Pendahuluan}

Sistem Pendukung Keputusan merupakan pengambilan keputusan yang menginformasikan modelmodel keputusan untuk memecahkan masalah yang sifatnya semi terstruktur atau yang tidak terstruktur, Penyelsaian suatu system tersetruktur berhasil membentuk suatu penyelsaian macam masalah yang dapat diselesaikan dengan sistem ini [1]. Penerapan aplikasi topsis di kecerdasan Sebagai Sistem Pendukung Keputusan Dalam Menentukan Kenaikan Jabatan Bagi Karyawan[2], metode ini dapat menyeleksi calon penerima Jamkesmas dengan baik dengan mengacu pada kriteria dari masing-masing warga Kota Bengkulu.

Penerapan Metode AHP Dan TOPSIS Sebagai Sistem Pendukung Keputusan Dalam Menentukan Kenaikan Jabatan Bagi Karyawan, Metode ini dipilih karena metode digunakan untuk pembanding kriteria dimana untuk mengukur tingkat kepentingan setiap kriteria dan metode TOPSIS ini merupakan suatu metode yang didasarkan pada konsep bahwa alternatif terbaik tidak hanya memiliki dari jarak terpendek dari solusi ideal positif tetapi juga memiliki jarak terjauh dari solusi ideal negatif dengan demikian metode TOPSIS untuk sangat cocok untuk perhitungan penentuan calon penerima Jamkesmas. Dengan menggunakan metode-metode tersebut akan bisa menyeleksi calon penerima Jamkesmas dengan baik dengan mengacu pada kriteria dari masing-masing warga Kota Bengkulu. Apabila pengambilan keputusan dibantu dengan sistem pendukung keputusan komputerisasi maka subyektifitas dapat dikurangi dan akan menjadi obyektifitas. Selain itu, sistem ini diharapkan akan mempermudah dan mempercepat petugas Balai Kota Bengkulu dalam menyeleksi calon peserta Jamkesmas. Dengan demikian hanya warga yang berhak mendapatkan Jamkesmas yang layak terpilih. Sistem pendukung keputusan ini hanyalah sebagai alat bantu untuk menghasilkan keputusan yang terbaik 4 dari berbagai informasi yang diperoleh, sedangkan keputusan akhir tetap dengan pengambil keputusan (Decision Maker). 
Dalam penelitian ini akan dibangun sistem pendukung keputusan kelompok dengan menggunakan Technique for Order Preference by Similarity to Solution dan Borda. Metode TOPSIS ini menentukan nilai bobot untuk setiap atribut, kemudian dilanjutkan dengan proses peringkat yang akan menyeleksi alternatif terbaik dari sejumlah alternatif yang ada dan merupakan sebagai referensi dari setiap pengambil keputusan. Sistem ini dapat menghasilkan urutan peringkat Penerima PKHdi Dinas Sosial Kota Bengkulu Menggunkan Metode Topsis, sehingga dapat membantu para decision maker untuk mendapatkan keputusan terbaik[7].

\section{Metodologi}

\section{A. Tahap Penelitian}

1. Pengumpulan Data

2. Analisa Sistem

3. Perancangan

4. Implementasi Dan Pengujian

\section{B. Pengumpulan data}

1. Observasi

Memperoleh data dengan melakukan pengamatan secara langsung terhadap objek yang di teliti yaitu pada sistem Program Keluarga Harapan (PKH) di Dinas Sosial Kota Bengkulu untuk melihat sampel.

2. Studi Pustaka

Mengumpulkan data dari buku-buku yang ada hubungannya dengan permasalahan yang dibahas.

\section{Dasar Teori Sistem Pendukung Keputusan}

Sistem pendukung keputusan membuat sistem menjadi terarah dan teridentifikasi menurut jenis dan keputusan sehingga system cerdas memberikan informasi sesuai dengan kebutuhan yang diinginkan sehingga menjadikan sistem itu berguna dan bermanfaat[3]. Konsep DSS hanyalah sebatas pada kegiatan membantu para manajer melakukan penilaian serta menggantikan posisi dan peran manajer [4].

\section{Menentukan nilai bobot seleksi setiap kreteria}

Tabel 1 Nilai bobot Kreteria

\begin{tabular}{clc}
\hline Kriteria & \multicolumn{1}{c}{ Keterangan } & Bobot \\
\hline \multirow{2}{*}{ C1 } & $\begin{array}{l}\text { Tidak mempunyai sumber mata pencaharian dan atau mempunyai sumber } \\
\text { mata pencaharian tetapi tidak mempunyai kemampuan memenuhi } \\
\text { kebutuhan dasar; } \\
\text { Mempunyai dinding rumah terbuat dari bambu/kayu/tembok dengan } \\
\text { kondisi tidak baik/kondisi rendah, termasuk tembok yang sudah } \\
\text { usang/berlumut atau tembok tidak diplester; }\end{array}$ & 5 \\
C3 & $\begin{array}{l}\text { Luas lantai rumah kecil kurang dari } 8 \mathrm{~m} \text { / orang dan } \\
\text { Mempunyai penerangan bangunan bangunan tempat tinggal bukan dari } \\
\text { listrik atau listrik tanpa meteran; } \\
\text { Mempunyai kemampuan hanya menyekolahkan anaknya sampai jenjang } \\
\text { pendidikan Sekolah Lanjutan Tingkat Pertama; }\end{array}$ & 5 \\
& & 3 \\
\hline
\end{tabular}

\section{Matrik keputusan}

3.

Matrik keputusan adalah menyusun hasil nilai masing-masing alternatif untuk setiap kriteria-kriteria yang telah dinilai oleh PKH [5].

Tabel 2 Bobot Kreteria

\begin{tabular}{cccccc}
\hline \multirow{2}{*}{ Alternatif } & \multicolumn{5}{c}{ Kriteria } \\
& C1 & C2 & C3 & C4 & C5 \\
\hline A1 & 1 & 0.75 & 1 & 0.75 & 1 \\
A2 & 0.5 & 0.5 & 0.5 & 0.5 & 0.75 \\
A3 & 0.5 & 0.5 & 0.75 & 0.75 & 1 \\
A4 & 1 & 0.75 & 1 & 0.5 & 0.75 \\
A5 & 0.5 & 0.75 & 1 & 0.75 & 1 \\
A6 & 0.5 & 0.75 & 0.5 & 0.5 & 0.75 \\
Bobot & 5 & 4 & 5 & 3 & 2 \\
\hline
\end{tabular}

Matrik keputusan ternormaliasi terbobot adalah melakukan rangking kinerja setiap alternatif Ai pada setiap kriteria $\mathrm{Cj}$ yang ternormalisasi. Dengan melakukan Krtiteria dibagi dengan akar setiap kriteria yang dipangkatkan[6].

$$
1 / \mathrm{SQRT}\left(1^{\wedge} 2+0.5^{\wedge} 2+0.5^{\wedge} 2+1^{\wedge} 2+0.5^{\wedge} 2+0.5^{\wedge} 2\right)=0.5774
$$


Tabel 3 Hasil bobot Kreteria

\begin{tabular}{cccccc}
\hline \multirow{2}{*}{ Alternatif } & \multicolumn{5}{c}{ Kriteria } \\
& C1 & C2 & C3 & C4 & C5 \\
\hline A1 & 0.5774 & 0.4523 & 0.4961 & 0.4804 & 0.4619 \\
A2 & 0.2887 & 0.3015 & 0.2481 & 0.3203 & 0.3464 \\
A3 & 0.2887 & 0.3015 & 0.3721 & 0.4804 & 0.4619 \\
A4 & 0.5774 & 0.4523 & 0.4961 & 0.3203 & 0.3464 \\
A5 & 0.2887 & 0.4523 & 0.4961 & 0.4804 & 0.4619 \\
\hline
\end{tabular}

\section{Design User Interface (UI)}

\section{Tampilan Input Kriteria}

Tampilan form input kriteria adalah rancangan form untuk memasukkan data kritera atau item penilaian yang akan dinilai oleh langsung pejabat yang ditugaskan. Nilai atribut postif dan negatif adalah apabila nilai kriteria

semakin besar semakin baik maka atribut postif(+) dan apabila semakin besar nilai kritera semakin tidak baik maka nilai atribtunya bernilai negatif (-).

\begin{tabular}{|ll|}
\hline & INPUT DATA KRITERIA \\
\hline Jenis PKH & $X(3)$ \\
Kode Kriteria & $X(30)$ \\
Nama Kriteria & ----- Pilih Penerima----- \\
Nilai Atribut (+/-) & $\times(10)$ \\
Bobot Nilai & SIMPAN \\
& \\
& \\
& \\
& \\
\end{tabular}

Gambar 1. Tampilan Menu Utama

2. Tampilan Form Input Bilangan Topsis

Rancangan form input bilangan Topsisadalah digunakan untuk memasukan nilai Topsisyang akan dibunakan sebagai pilihan yang akan digunakan oleh pejabat penilai.

\begin{tabular}{|c|c|}
\hline \multicolumn{2}{|c|}{ INPUT DATA TOPSIS } \\
\hline Kode Bobot & $X(30)$ \\
\hline Nama Bobot & X(30) \\
\hline NIIal TOPSIS & 9.99 \\
\hline & SIMPAN \\
\hline
\end{tabular}

Gambar 2. Form Input Bilangan Topsis

\section{Rancangan Input Penilaian}

Rancangan form input penilaian adalah rancangan yang digunakan oleh team penilai dalam melakukan seleksi dengan memilih pegawai yang akan diseleksi dan setiap kritera memilih bilangan Topsis yang merupakan nilai dari kriteria yang telah dipilih oleh team penilai.

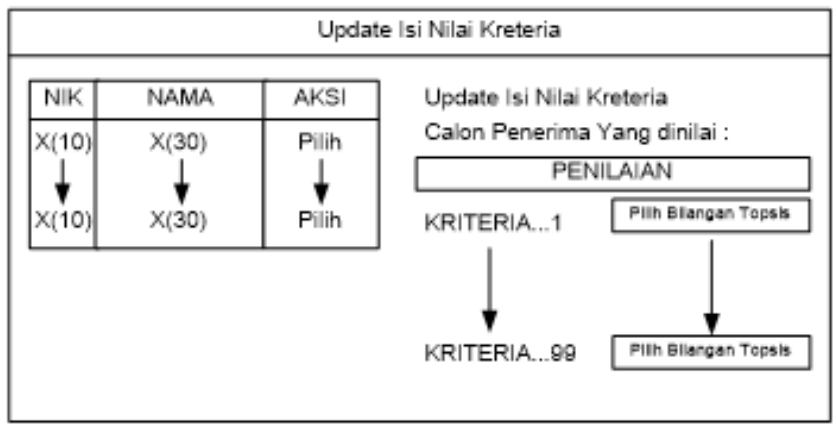


Gambar 3. Form Input Penilaian

\section{Hasil dan Pembahasan}

Menu form input kriteria adalah rancangan form untuk memasukkan data kritera atau item penilaian yang akan dinilai oleh langsung pejabat yang ditugaskan. Nilai atribut postif dan negatif adalah apabila nilai kriteria semakin besar semakin baik maka atribut postif $(+)$ dan apabila semakin besar nilai kritera semakin tidak baik maka nilai atribtunya bernilai negatif (-).

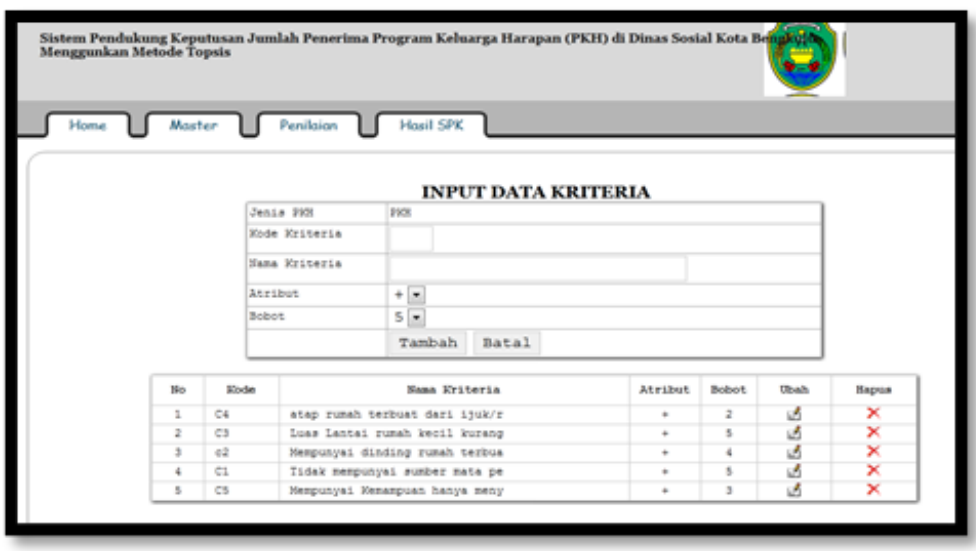

Gambar 4. Form Input Kriteria

Menu form input bilangan Topsisadalah digunakan untuk memasukan nilai Topsisyang akan dibunakan sebagai pilihan yang akan digunakan oleh pejabat penilai.

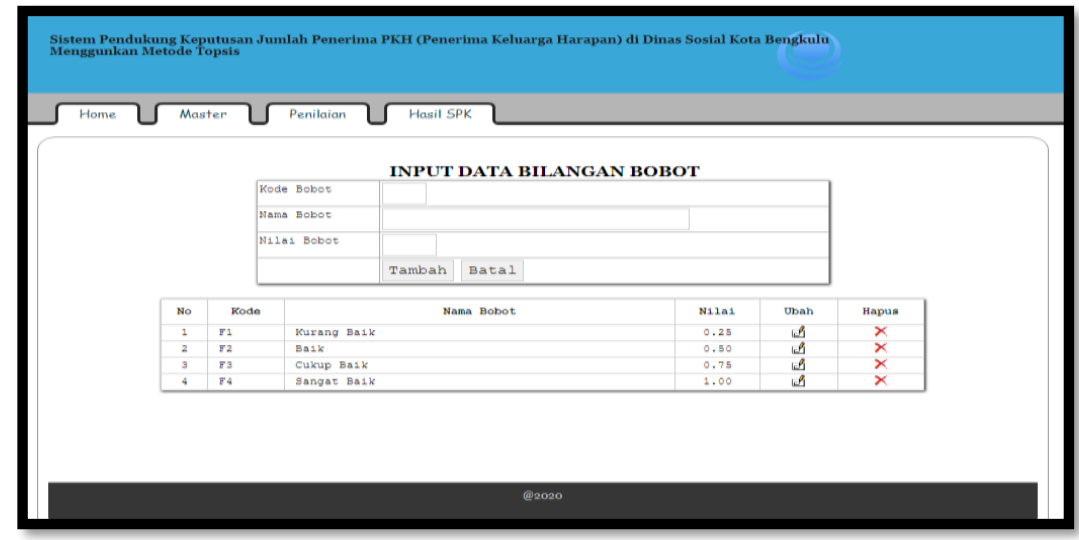

Gambar 5. Form Input Bilangan Topsis

Menu form input penilaian adalah rancangan yang digunakan oleh team penilai dalam melakukan seleksi dengan memilih pegawai yang akan diseleksi dan setiap kritera memilih bilangan Topsis yang merupakan nilai dari kriteria yang telah dipilih oleh team penilai.

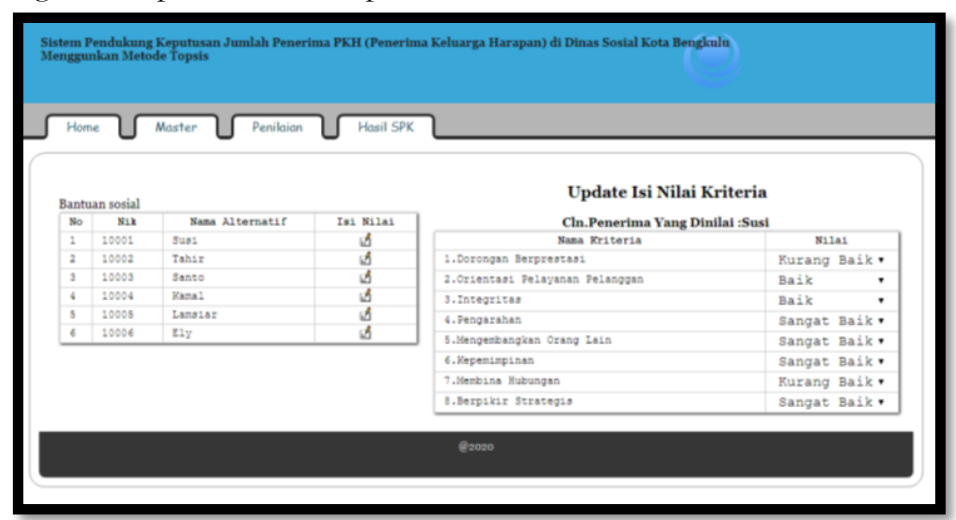


Gambar 6. Form Input Penilaian

Menu output hasil proses SPK dengan metode TOPSISdengan membuat tabel hasil perangkingan.

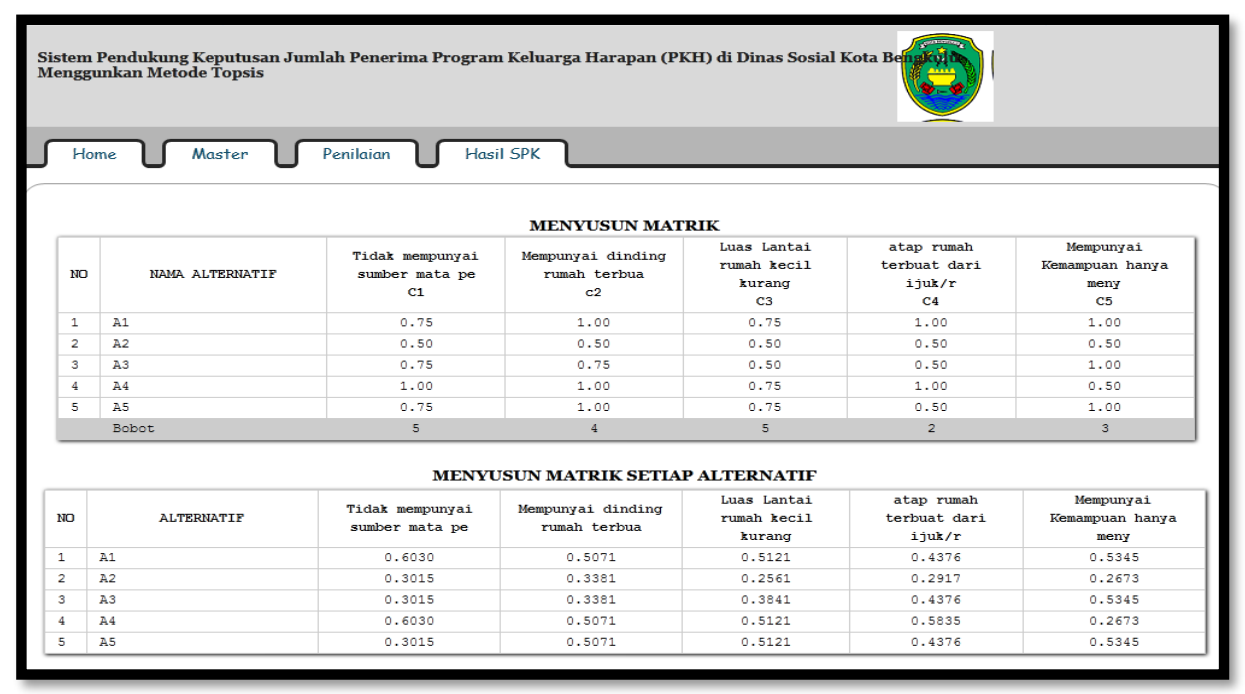

\section{Kesimpulan}

Adapun kesimpulan yang dapat diambil dari penelitian Sistem Pendukung Keputusan Jumlah Penerima PKH di Dinas Sosial Kota Bengkulu Menggunkan Metode Topsis adalah sebagai berikut : Pengambilan keputusan dengan sesuai kriteria menggunakan metode Topsis sehingga bisa menjadi tolak ukur dalam pengambilan keputusan, Dengan metode ini dapat mempermudah dalam pencarian data yang akurat sebanyak apapun responden yang akan diusulkan berdasarkan kriteria maka sistem akan melacak dan memberikan keputusan yang tepat, Mempermudah admin melakukan pencarian dalam berdasarkan bobot dan kreteria.

\section{Ucapan Terima Kasih}

a. Ucapan Terima Kasih kepada Prof.Dr.kamaludin, SE.MM, selaku Rektor Universitas Dehasen Bengkulu.

b. Kepada Ibu Dr.Suwarni Selaku Kepala BAU untuk mensuport Dosen Untuk meningkatkan Kinerja Dosen dibidang Penelitian

c. Dekan Fakultas Ilmu Komputer Bapak.Siswanto, SE.M.Kom

\section{Daftar Pustaka}

[1] Jogiyanto Hartono. 2005. Analisis \& Disain Sistem Informasi Pendekatan terstruktur Teori dan Praktek Aplikasi Bisnis. ANDI. Yogyakarta.

[2] Budi Sutejo Dharma Oetomo, Perencanaan dan Pembangunan Sistem Informasi, Penerbit Andi, Yogyakarta.

[3] Efrain Turban, 2001, Jay E.Aronson, Ting Peng Liang, Decision Support Systems and Inteligent Systems, Edisi 7, Jilid 1.

[4] Purwantara I Made. System Pendukung Keputusan Kelompok Evaluasi Infrakstruktur Jalan Raya Terhadap Kemacetan Lalu Lintas Menggunakan Metode TOPSIS dan Borda. Yogyakarta : Universitas Gadjah Mada.

[5] Fathansyah 2015. Basis Data, Informatika Bandung.

[6] Abdul Wahid dan Mohammad Labib, 2012, Kejahatan Mayantara (Cyber Crime), Bandung: PT Refika Aditama;

[7] Jogiyanto, H.M., 2005, Analysa dan Desain Sistem Informasi: Pendekatan Terstruktur Teori dan Praktik Aplikasi Bisnis, ANDI, Yogyakarta

[8] Abdul Kadir. 2003. HTML, CSS, JAVASCRIPT, and PHP are examples of web programming languages.ANDI. Yogyakarta 